\title{
1. The Legitimacy of Standardisation as a Regulatory Technique in the EU - A Cross-disciplinary and Multi-level Analysis: An Introduction
}

Mariolina Eliantonio and Caroline Cauffman

\section{INTRODUCTION}

\subsection{Standardisation: A Topic for Lawyers?}

Standardisation is a topic which has been widely studied from an economic and political science perspective: the first international publications on standardisation were of an economic nature. ${ }^{1}$ They were followed by studies carried out from a political science perspective. ${ }^{2}$

1 The literature on this topic is extensive. Without any claim to exhaustiveness, see, for example, Franklin Edward Powell, Some Aspects of Standardization and Economic Theory (Catholic University of America 1947); H Landis Gabel, Product Standardization and Competitive Strategy (Elsevier Science 1987); H Landis Gabel, Competitive Strategies for Product Standards: The Strategic Use of Compatibility Standards for Competitive Advantage (McGraw-Hill 1991); Peter Grindley, Standards, Strategy, and Policy: Cases and Stories (Oxford University Press 1995); Carmen Matutes and Pierre Regibeau, 'A Selective Review of the Economics of Standardization. Entry Deterrence, Technological Progress and International Competition' (1996) European Journal of Political Economy 12(2): 183-209. More recently, see Knut Blind, The Economics of Standards: Theory, Evidence, Policy (Edward Elgar 2004).

2 Susanne K Schmidt and Raymund Werle, Coordinating Technology: Studies in the International Standardization of Telecommunications (MIT Press 1998); Kenneth W Abbott and Duncan Snidal, 'International Standards and International Governance' (2001) Journal of European Public Policy 8(3): 345-70; Tim Büthe and Walter Mattli, 'Setting International Standards: Technological Rationality or Primacy of Power?' (2003) World Politics 56(1): 1-42; Tim Büthe and Walter Mattli, 'International Standards and Standard-Setting Bodies' in David Coen, Wyn Grant and Graham Wilson (eds), The Oxford Handbook of Business and Government (Oxford University 
Also, specifically at the European level, it was mostly political scientists who studied the phenomenon of standardisation ${ }^{3}$ to highlight its role and benefits for the EU market, ${ }^{4}$ or to discuss the reasons for resorting to standardisation in the process of EU governance. ${ }^{5}$ Political scientists in particular have engaged with standards as a tool and policy instrument in the context of the literature studying the new modes of governance and regulation. ${ }^{6}$ Also mostly from a political science perspective, standardisation has formed part of the research into the legitimacy of using rules of private origin in the public domain. ${ }^{7}$

Press 2010) 440-71; Tim Büthe and Walter Mattli, The New Global Rulers: The Privatization of Regulation in the World Economy (Princeton University Press 2011).

3 See for example Jacques Pelkmans, 'The New Approach to Technical Harmonization and Standardisation' (1987) Journal of Common Market Studies 25(3): 249-69; Michelle Egan, 'Regulatory Strategies, Delegation and European Market Integration' (1998) Journal of European Public Policy 5(3): 485-506; Michelle Egan, Constructing a European Market: Standards, Regulation and Governance (Oxford University Press 2001).

4 Alec S Sweet and Wayne Sandholtz, 'Integration, Supranational Governance, and the Institutionalization of the European Polity' in Alec S Sweet and Wayne Sandholtz, European Integration and Supranational Governance (Oxford University Press 1998).

5 Giandomenico Majone, 'The Rise of the Regulatory State in Europe' (1994) West European Politics 17(3): 77-101.

6 Stefano Bartolini, 'New Modes of European Governance: An Introduction' in Adrienne Héritier and Martin Rhodes (eds), New Modes of Governance in Europe: Governing in the Shadow of Hierarchy (Palgrave Macmillan 2011) 1-18; Richard Bellamy et al, 'Evaluating Trustworthiness, Representation and Political Accountability' in Adrienne Héritier and Martin Rhodes (eds), New Modes of Governance in Europe: Governing in the Shadow of Hierarchy (Palgrave Macmillan 2011) 135-62; Gráinne de Burca and Joanne Scott, 'New Governance, Law and Constitutionalism' in Gráinne de Burca and Joanne Scott (eds), Law and New Governance in the EU and the US (Hart Publishing 2006) 1-12.

7 See: Martin Rhodes and Jelle Visser, 'Seeking Commitment, Effectiveness and Legitimacy: New Modes of Socio-Economic Governance in Europe' in Adrienne Héritier and Martin Rhodes (eds), New Modes of Governance in Europe: Governing in the Shadow of Hierarchy (Palgrave Macmillan 2011) 104-34; Raymund Werle and Eric J Iversen, 'Promoting Legitimacy in Technical Standardization' (2006) Science, Technology \& Innovation Studies 2(1): 19-39; Michael T Greven, 'The Informalization of Transnational Governance: A Threat to Democratic Government' in Edgar Grande and Louis W Pauly (eds), Complex Sovereignty: Reconstructing Political Authority in the Twenty-First Century (University of Toronto Press 2005) 261-84; Adrienne Héritier, 'The Accommodation of Diversity in European Policy-Making and its Outcomes: Regulatory Policy as a Patchwork' (1996) Journal of European Public Policy 3(2): 149-67; Adrienne Héritier, 'New Modes of Governance in Europe: Policy-Making Without Legislating?' (2002) IHS Political Science Series 81: 1-24; Christian Joerges and Ellen Vos, 'Structures of Transnational Governance and Their 
Since standards are essentially non-binding, they have long been neglected by lawyers (especially public lawyers). ${ }^{8}$ Unsurprisingly, the first legal contributions belonged to the legal fields closely related to the non-legal fields that had already discovered standardisation as a field of research. Given the close relationship between industrial organisation and competition law, competition lawyers were among the first to look at standardisation through a legal lens and to investigate the compatibility of standardisation with competition law and intellectual property law. ${ }^{9}$ As an expression of a form of private regulation, if explored in legal scholarship, standardisation is also increasingly studied in the context of private law. ${ }^{10}$

Standardisation has also been examined from the perspective of international economic law. ${ }^{11}$ Given increasing globalisation, the absence of a world

Legitimacy', in John AE Vervaele (ed), Compliance and Enforcement of European Community Law (Kluwer Law International 1999) 71-93; Dagmar Schiek, 'Private Rule-Making and European Governance - Issues of Legitimacy’ (2007) European Law Review 32: 443-66.

8 Indeed, standardisation has been considered 'a much-neglected area of social science research, attracting much less attention than it deserves': Harm Schepel, The Constitution of Private Governance: The Product Standards in the Regulation of Integrating Markets (Hart Publishing 2005) 2. For notable exceptions see Harm Schepel and Josef Falke, Legal Aspects of Standardisation in the Member States of the EC and EFTA: Vol. 1: Comparative Report (European Commission 2000); Harm Schepel and Josef Falke (eds), Legal Aspects of Standardisation in the Member States of the EC and EFTA, Vol. 2: Country Reports (European Communities 2000); Josef Falke, Rechtliche Aspekte der Normung in den EG-Mitgliedstaaten und der EFTA (European Commission 2000). It should also be noted that the private law consequences of standardisation received more attention: see for example Carola Glinski, Die rechtliche Bedeutung der privaten Regulierung globaler Produktionsstandards (Nomos 2010).

9 Piotr Staniszewski, 'The Interplay between IP Rights and Competition Law in the Context of Standardization' (2007) Journal of Intellectual Property Law \& Practice 2(10): 666-81; Björn Lundqvist, Standardization under EU Competition Rules and US Antitrust Laws: The Rise and Limits of Self-Regulation (Edward Elgar 2014); Jorge L Contreras, The Cambridge Handbook of Technical Standardization Law (Cambridge University Press 2017).

10 See for instance Barend van Leeuwen, European Standardisation of Services and Its Impact on Private Law: Paradoxes of Convergence (Hart Publishing 2017); Mislav Mataija, Private Regulation and the Internal Market: Sports, Legal Services and Standards Setting in EU Economic Law (Oxford University Press 2016); the Special Issue edited by Paul Verbruggen of (2019) Review of European Private Law 'Regulating Private Regulators: Understanding the Role of Private Law' 27(2); Marta Cantero Gamito and Hans-W Micklitz, The Role of the EU in Transnational Legal Ordering: Standards, Contracts, and Codes (Edward Elgar 2019).

11 See for example Steven Bernstein and Erin Hannah, 'Non-State Global Standard Setting and the WTO: Legitimacy and the Need for Regulatory Space' (2008) Journal 
legislator and the fact that the traditional legal method of international lawmaking (treaties) is too slow to deal with rapid economic and societal developments, standardisation came to the attention of legal scholars interested in legal harmonisation, global law and law beyond the state. ${ }^{12}$ Recently, a number of multidisciplinary projects have been seen. ${ }^{13}$ Finally, in the aftermath of the James Elliot ruling of the Court of Justice of the European Union, ${ }^{14}$ European standardisation has had increased attention from legal scholars, and especially public lawyers. ${ }^{15}$

With this book, we aim to contribute to the literature on standardisation by examining a topical, yet still open question surrounding its use: the legitimacy of standardisation as a regulatory technique in the European Union.

\subsection{Standardisation in the EU in Its 'Infinite Variety'16}

Standardisation takes various shapes and forms in the European Union legal system. One striking example is that of the so-called New Approach, a regulatory technique introduced in the 1980 s to further market integration. ${ }^{17}$ Under this strategy, the EU legislator lays down the so-called essential requirements concerning health and safety of certain products, while the more detailed technical rules in the form of Harmonised European Standards (HESs) are developed by the European Standardisation Organisations (ESOs), upon request by the European Commission, so as to implement the essential requirements. Subsequently, the Commission publishes the reference to the HES in the Official Journal. At this stage, the HES acquires a so-called presumption of conformity, meaning that an economic operator following the HES is

of International Economic Law 11(3): 575-608; Jaye Ellis, 'Scientific Expertise and Transnational Standards: Authority, Legitimacy, Validity' (2017) Transnational Legal Theory 8(2): 181-201.

12 See for example John J Kirton and Michael J Trebilcock, Hard Choices, Soft Law: Voluntary Standards in Global Trade, Environment and Social Governance (Routledge 2016).

13 See for example Panagiotis Delimatsis, The Law, Economics and Politics of International Standardization (Cambridge University Press 2015).

14 C-613/14, James Elliott Construction Limited v Irish Asphalt Limited, ECLI:EU: C:2016:821.

15 See, for example, the Special Issue by Mariolina Eliantonio and Megi Medzmariashvili, 'Hybridity under Scrutiny: How European Standardization Shakes the Foundations of EU Constitutional and Internal Market Law' (2017) Legal Issues of Economic Integration 44(4): 323-35.

${ }_{16}$ This apt figure is borrowed by RR Baxter, 'International Law in "Her Infinite Variety"' (1980) International and Comparative Law Quarterly 29(4): 549-66.

17 Council Resolution (85/C 136/01) of 7 May 1985 on a New Approach to Technical Harmonisation and Standards [1985] C 136/1. 
presumed to be in compliance with the mandatory essential requirements. A number of contributions to this book examine legitimacy questions linked to HESs and the New Approach in general. ${ }^{18}$

However, standards enter the European Union legal system in a myriad of other ways. First of all, standards may be developed by the ESOs outside the New Approach framework. Second, a huge range of standards on the most diverse topics is developed by bodies outside the EU legal system, established in connection with international treaties or as purely private fora and consortia, with various (public and private) membership criteria, procedural and voting rules and transparency requirements. In turn, as discussed in the contribution to this book by Volpato and Eliantonio, these European or international standards may be referred to in binding legislation, or in soft law measures, or may sometimes be incorporated verbatim in EU measures. Without any pretence of exhaustiveness, in this book we aim at presenting various sectorial perspectives on standardisation, in order to show the varied nature of the phenomenon at EU level and its enormous relevance for policy fields which are as diverse as pharmaceutical authorisations, telecommunications and food safety, yet which all raise comparable legitimacy-related questions.

\subsection{Standardisation: Its Benefits and Challenges}

Standardisation has been praised in literature for its many advantages: private regulation generally has been regarded as delivering a high level of expertise, since industrial players in technical sectors possess up to date knowledge and are better equipped to tackle technical and complex issues. ${ }^{19}$ This perspective also resonates with the Commission, which has stated that standardisation 'combines binding legislative and regulatory action with actions taken by the actors most concerned, drawing on their practical expertise' ${ }^{20}$ As a consequence, according to the Commission, private regulation will deliver a wider ownership of the policies and they have been designed by involving those most affected by them in their preparation and ultimately a higher level of compliance. ${ }^{21}$

Furthermore, in the eyes of the European Commission itself, 'standards support market-based competition and help ensure the interoperability of complementary products and services. They reduce costs, improve safety, and enhance competition. Due to their role in protecting health, safety, secu-

\footnotetext{
See in particular the contributions by Senden, Cuccuru and Röttger-Wirtz.

Mataija, above n. 10, 12.

Communication from the Commission, 'European governance - a white paper', 25 July 2001, COM(2001) 428 final, Section III.2. Emphasis added.
}

21 Ibid. 
rity, and the environment, standards are important to the public. ${ }^{22}$ They are ultimately considered a more cost-efficient method to address certain policy objectives. $^{23}$

In addition, private regulation, of which standardisation is an expression, can be regarded as more flexible, inclusive and responsive than the traditional 'Community' method, ${ }^{24}$ and as an expression of the principles of subsidiarity and proportionality. This is most evident in the view that the Commission has expressed on numerous occasions in the course of its engagement in the framework of the Better Regulation package.

Indeed, first with the Commission's White Paper on Governance, ${ }^{25}$ and later with the Better Regulation Programme of 2002, ${ }^{26}$ the use of non-legal instruments was supported as an alternative to binding legislation. The 2003 Interinstitutional Agreement on Better Law-Making establishes co-regulation an as alternative regulatory mechanism, again as an expression of subsidiarity. ${ }^{27}$ The EU's support for the use of co-regulation was later confirmed in the Commission Communication on Subsidiarity, in which the Commission made it clear that, when choosing the appropriate form of action, a partnership with private bodies, such as businesses, associations and trade unions, had to be considered as a less restrictive regulatory option. ${ }^{28}$ This preference has more recently been restated in the latest Better Regulation document of May 2015. ${ }^{29}$

In June 2016, the European Commission launched a 'Joint Initiative on Standardisation', a strategic policy document highlighting the Commission's intention to boost standardisation as a regulatory technique in order to enhance

22 https://ec.europa.eu/growth/single-market/european-standards/policy_en, accessed 1 February 2020.

23 Communication of the Commission to the European Parliament, the Council, the European Economic and Social Committee and the Committee of the Regions, Implementing the Community Lisbon programme: A strategy for the simplification of the regulatory environment, Brussels, 25 October 2005, COM(2005) 535 final, 7.

24 Herwig CH Hofmann, Gerard C Rowe and Alexander H Türk, Administrative Law and Policy of the European Union (Oxford University Press 2011) 326-8; Mataija, above n. 10, 12.

25 European Commission, 'European Governance: A White Paper', COM(2001) 428 final.

26 Commission Action Plan, 'Simplifying and Improving the Regulatory Environment' (Communications) $\operatorname{COM}(2002) 278$ final.

27 Interinstitutional Agreement on Better Law-Making [2003] OJ C-321/01.

28 Communication of the Commission to the Council and European Parliament, The principle of subsidiarity, 27 October 1992, SEC(92) 1990 final, 13 and 14.

${ }_{29}$ Communication from the Commission to the European Parliament, the Council, the European Economic and Social Committee and the Committee of the Regions, 'Better regulation for better results - An EU agenda', 19 May 2015, COM(2015) 215 final. 
the competitiveness and growth of the European economy and allow it to maintain a leading position in the world in terms of technical developments and global trade. In this document, standards are presented as a voluntary, market-driven, fast and reliable instrument to enhance the European role as a global trade player, while at the same time ensuring an inclusive process where consumers have a say, and where wider societal and environmental interests are duly taken into account.

Notwithstanding these perceived benefits, the use of standardisation as a regulatory technique could be considered problematic. First of all, the actions of private regulators do not have to abide by the same transparency requirements imposed on public authorities, and they are not subject to the same mechanisms of control and accountability as governmental players. Furthermore, as they are developed by unelected private bodies, standards lack the democratic credentials which are generally attributed to legislation. Earlier research conducted on the European standardisation process has indeed revealed that very fundamental constitutional concerns can be expressed with regard to the use of HESs to support legislation. ${ }^{30}$ With this book, we aim to broaden and deepen these earlier findings, by exploring the legitimacy concerns (the 'law's problem', as has been aptly phrased in earlier seminal research $^{31}$ ) that can be expressed with respect to the use of standardisation as a regulatory technique in the European Union.

\section{INPUT, OUTPUT AND THROUGHPUT LEGITIMACY OF STANDARDISATION IN THE EUROPEAN UNION: THE 'LAW'S PROBLEM' WITH STANDARDISATION PUT TO THE TEST}

The overarching research question of this book is whether the process of standardisation, with its economic and trade advantages, provides sufficient legitimacy guarantees. As stated by Senden in this book, '[T] his assessment relates to the very foundations and exercise of the authority and power involved in the EU standardisation process' ${ }^{32}$ This assessment is all the more urgent in the context of the European Union, given its 'constitutionalisation attempts'

\footnotetext{
30 Eliantonio and Medzmariashvili, supra n. 15, 323-35; Paul Verbruggen, 'Does Co-regulation Strengthen EU's Legitimacy?' (2009) European Law Review 15(4): 425.

31 The phrase borrowed from the article by Christian Joerges, Harm Schepel and Ellen Vos, 'The Law's Problem with the Involvement of Non-Governmental Actors in Europe's Legislative Process: The Case of Standardisation under the "New Approach"', EUI Working Paper Law No 99/9 (1999).

32 Senden, p. 22.
} 
which culminated with the Lisbon Treaty and the incorporation of the Charter of Fundamental Rights into binding secondary law. ${ }^{33}$

While it is rather straightforward to link the notion of legitimacy to that of the exercise of public power, it is a more complicated issue to provide a definition for this term. Throughout history, numerous philosophers, anthropologists and political scientists have developed complex definitions and theories of legitimacy. It is not the purpose of this book to provide an overview or assess the value of these definitions and theories. ${ }^{34}$ For the purposes of this book, the starting point will be the definition of legitimacy provided by Scharpf, who distinguishes between 'input' and 'output legitimacy'. ${ }^{35}$ We further extend the analysis to the additional dimension of 'throughput' legitimacy, which has been advanced by Schmidt. ${ }^{36}$ In what follows, these three aspects of legitimacy will be considered in light of the findings of the contributions to this book.

\subsection{Input Legitimacy: From Bad to Worse?}

'Input legitimacy' refers to the representative character of the rule-making process. In the context of the European Union, input legitimacy is said to be judged 'in terms of the EU's responsiveness to citizen concerns as a result of participation by the people' ${ }^{37}$ As Senden puts it in her contribution, input legitimacy requires that 'all citizens' interests are sufficiently taken on board and protected in privately set standards and therefore also on rules and procedures that allow for equal representation and balancing of all interests at stake'. ${ }^{38}$ Several of the contributions to this volume have highlighted a number of concerns when it comes to participation in the standardisation processes which are relevant for the European Union.

Specifically with regard to the European standardisation process, a number of input legitimacy requirements are contained in Articles 3 to 7 of the

\footnotetext{
33 As noted by Senden, p. 36 and following.

34 For such an overview, see for example Vincent Depaigne, Legitimacy Gap: Secularism, Religion, and Culture in Comparative Constitutional Law (Oxford University Press 2017); Robert D Lamb, Rethinking Legitimacy and Illegitimacy: A New Approach to Assessing Support and Opposition across Disciplines (Rowman \& Littlefield 2014).

35 Fritz Scharpf, Governing in Europe: Effective and Democratic? (Oxford University Press 1999).

36 Vivien A Schmidt, 'Democracy and Legitimacy in the European Union Revisited: Input, Output and 'Throughput' (2013) Political Studies 61: 2-22.

37 Ibid, 2.

38 Senden, p. 27.
} 
Standardisation Regulation, ${ }^{39}$ which provide for a number of participation and transparency obligations for European Standardisation Organisations. Earlier research, however, has cast some doubts on the adequacy of the current framework to ensure real participation of - especially - societal stakeholders in the European standardisation process. ${ }^{40}$

Furthermore, as Cuccuru points out, the principles established by the Standardisation Regulation need concretisation, which the internal rules of the ESOs must provide. Whether these rules provide for sufficient input legitimacy guarantees is critically discussed by Cauffman and Gérardy in the context of competition law. Indeed, in order to avoid the risk of being caught by Article 101 TFEU, standardisation organisations can be expected to strive to fulfil the safe harbour requirements set out by the European Commission in its Guidelines on Horizontal Cooperation Agreements, ${ }^{41}$ which contain elements of input legitimacy, such as participation, transparency and accessibility.

Cauffman and Gérardy, however, show that the internal procedures applied within CEN-CENELEC do not guarantee sufficient participation, transparency and accessibility. For example, SMEs are de facto excluded from participation in the technical committees preparing the standards, because they lack the financial means to participate. The so-called Annex III organisations, which represent the interests of consumers (ANEC), environment (ECOS), trade unions (ETUC) and smaller companies (SBS), only have the status of observers, without voting rights. While in principle anyone is entitled to comment on the draft norms negotiated within the Technical Committees during the Public Enquiry, it is generally very difficult to know about every public enquiry that is going on. Furthermore, the reports of the Technical Committees often only contain the outlines of the meetings, which makes it impossible to verify whether there was collusion between the participants.

The problem of insufficient input legitimacy becomes even more evident in the case of standards that are not developed by the European Standardisation Organisations, since they do not need to comply with the procedural requirements set out in the abovementioned Articles of the Standardisation Regulation.

De Bellis shows this clearly with respect to standards in the financial sector. She explains how compliance with global financial standards, which are

39 Regulation (EU) No 1025/2012 of the European Parliament and of the Council of 25 October 2012 on European standardisation, OJ L 316, 14.11.2012, 12-33.

40 Morten Kallestrup, 'Stakeholder Participation in European Standardization: A Mapping and an Assessment of Three Categories of Regulation' (2017) Legal Issues of Economic Integration 44(4): 381-93.

${ }^{41}$ Communication from the Commission - Guidelines on the applicability of Article 101 of the Treaty on the Functioning of the European Union to horizontal co-operation agreements Text with EEA relevance, OJ C 11, 14.1.2011, pp. 1-72. 
developed by an array of public, private and hybrid bodies, is increasingly less voluntary and de facto compels the adoption of rules modelled on the standards even within jurisdictions the regulatory authorities of which were not involved in the drafting of the standards. Several global standards in this area are also incorporated into binding secondary EU law. With respect to input legitimacy, she highlights that a number of concerns can be expressed with respect to a balanced geographical representation in the process of standard-setting in this area, as well as with regard to the fact that many organisations have a private nature and are composed of practitioners.

Similar conclusions resonate with respect to the standards which are relevant in the context of the internet and the World Wide Web. With respect to those standards, Schoenmaekers indicates that many of them are developed by private ICT forums and consortia and thus outside the ESOs and the scope of participatory and transparency requirements provided in the Standardisation Regulation. However, Schoenmaekers points out that Article 13(1) of the Regulation allows the reference to such standards in public procurement procedures as so-called common technical specifications provided that they are identified by the Commission as meeting the requirements set out in Annex II of the Regulation itself. Annex II requires inter alia that the specifications are developed by non-profit organisations through processes that are open, transparent and rely on consensus. Moreover, the Commission can only take this initiative after consultation with the European multi-stakeholder platform on ICT standardisation, which includes European standardisation organisations, Member States and relevant stakeholders. This platform will assess whether the requirements of Annex II are met. This guarantees a certain level of input legitimacy. However, in the opinion of Schoenmaekers, this is insufficient, given the facts that the European Commission is not composed of democratically elected representatives and the consultation of the European multi-stakeholder platform on ICT standardisation is only a light version of representation compared to the legal rules that are adopted by democratically elected representatives.

Low input legitimacy is also observed by Cantero with respect to the telecommunications sector. While standardisation in the telecoms sector finds its origin in the industry, currently several international and European standardisation bodies for telecoms are active in the field, in which governments are represented. However, often it is standards originally developed by industry consortia that are later incorporated by institutionalised standard-setting bodies. Although those bodies gradually allowed wider participation and the involvement of users in the development of technical standards, public influence is still limited. In particular, in international standard-setting bodies representation is de facto restricted, given the technical nature of the discussions and the high level of time and resources required. Furthermore, the EU 
regulatory framework for telecoms encourages, and in some cases requires, the implementation of standards adopted at international level. This process is problematic in terms of input legitimacy because these globally developed standards become binding EU law, but the standard-setting activity of international standard-setting bodies is not subject to the procedural principles contained in the Standardisation Regulation.

In food law, Bevilacqua discusses the example of food safety standards contained in the Codex Alimentarius and developed by the Codex Alimentarius Commission, as an executive body of FAO and WHO. These standards have a special status in the context of the WTO and therefore need to be complied with by the EU as any member of the WTO system. However, a number of input legitimacy concerns can be observed with respect to these standards. In particular, it is the opinion of the author that 'the indirect representation of national delegates ... appears to be insufficient, as the chain of representation is articulated in several steps that reduce the accountability of the decision-makers before their domestic constituencies' ${ }^{42}$

\subsection{Output Legitimacy: Some Findings of Success Far from the Lawyer's 'Comfort Zone'}

In addition to 'input legitimacy', 'output legitimacy' contributes to the legitimate character of rules. This aspect of legitimacy focuses not on representation in the rule-setting process ('governance by the people') but on the quality or broader benefits of the outcome of the rule-setting process, in our case the standards ('governance for the people') ${ }^{43}$. From the perspective of output legitimacy, the outcome of a rule-setting process is legitimate if and because it effectively promotes the common welfare, ${ }^{44}$ or, more specifically, if it is effective in meeting the economic and policy goals. ${ }^{45}$

Output legitimacy is a difficult topic for lawyers, as it entails evaluating policy outcomes on the basis of efficiency and efficacy criteria. ${ }^{46}$ The contributions in this book have not undertaken this kind of evaluation. Nevertheless, they do contain important insights pointing to the overall high level of output legitimacy of the standardisation process.

\footnotetext{
42 Bevilacqua, p. 263.

43 Scharpf, above n. 35, 6 .

44 Ibid.

45 Carol Harlow, 'Accountability as a Value in Global Governance and for Global Administrative Law' in Gordon Anthony, Jean-Bernard Auby, John Morison and Tom Zwart (eds), Values in Global Administrative Law (Hart Publishing 2011) 182.

46 Sébastien Mena and Guido Palazzo, 'Input and Output Legitimacy of Multi-Stakeholder Initiatives' (2012) Business Ethics Quarterly 22(3): 527-56.
} 
Although mainly focusing on input legitimacy, De Bellis indicates that global financial standards had long been praised for their effectiveness. However, after the financial crisis, these standards were criticised and their efficiency was called into question. According to De Bellis, this was not entirely justified. Nevertheless, the standards' output legitimacy should not be presumed, but must be analysed on a case by case basis.

Cantero also points to a high output legitimacy of standards issued in the telecoms sector. She explains that in the telecommunications sector, interoperability between networks, systems and services is essential. Interoperability enables a network or system to connect with another network or system. Practically, interoperability is achieved by the use of technical standards and specifications that are applied across national borders. This enables the provision of cross-border services, which is essential for the realisation of the internal market. It also facilitates competition by establishing the conditions for consumers to switch between operators, by increasing choice and reducing prices. These resulting benefits for consumers are so important that they might outweigh the flawed input legitimacy of the standards.

A somewhat less positive view is expressed by Bevilacqua with respect to food safety standards. The objectives of the Codex Alimentarius Commission are inter alia to protect consumers' health and ensure fair practices in the food trade. In order to ensure the output legitimacy of the Codex Alimentarius, the Codex Alimentarius Commission can include a risk assessment phase in the standard-setting procedure. During this phase, external independent risk assessors will perform studies and provide scientific non-binding opinions. These scientific reports are public and available on the web. According to Bevilacqua, the procedure nevertheless suffers from a number of weaknesses (also impinging on input and throughput legitimacy) that might ultimately undermine output legitimacy. First, the selection of the experts is not completely transparent and it is often not based on public and open competitions or tenders. Second, only the conclusion of the process is public and not the phases leading to the scientific report so that the rationale of the conclusion and the scientific approaches used are not publicly available. Third, the fact that experts are not remunerated might affect the neutrality of the experts since it might render them vulnerable to accepting payments from stakeholders in return for reaching the conclusion desired by the stakeholder. In addition, procedures (such as disclosure obligations and inspections) guaranteeing their neutrality are absent. As a consequence, the standards produced might not be the most effective in terms of achieving their policy goals. 


\subsection{Throughput Legitimacy: Not Able to Make Up for the Low Input Legitimacy}

As mentioned above, the literature on legitimacy has considered a third and additional element to establish the legitimacy of a decision-making process: that of throughput legitimacy. While input legitimacy questions the legitimacy of participation in the development process, throughput legitimacy questions the legitimacy of the design of the development process. ${ }^{47}$ According to Schmidt, throughput legitimacy 'is judged in terms of the efficacy, accountability and transparency of the EU's governance processes along with their inclusiveness and openness to consultation with the people.' 48

The contributions to this book raise a number of questions and points of criticism with respect to this aspect.

The contributions of Volpato and Eliantonio and of Röttger-Wirtz focus on the accountability aspect of the notion of throughput legitimacy, by examining specifically the judicial accountability aspect of standardisation as a regulatory technique. As Volpato and Eliantonio state, this is an aspect which cannot be overstated in the context of the standardisation process: first, in general, because 'the institutional bedrock of most rule of law models lies in judicial review as an independent review of the legality of administrative action'; ${ }^{4}$ second, because of the potential for judicial review to compensate for the abovementioned shortcomings of the standardisation process in terms of input legitimacy. Volpato and Eliantonio examine the way in which European and global standards enter the EU legal system and conclude that the attitude of the Court of Justice vis-à-vis the control of these standards appears somewhat contradictory. This is because the Court seems to be exercising a closer scrutiny of harmonised European standards, which are formally not binding, than it does with other kinds of standards which are incorporated by reproduction in EU law and thus constitute binding secondary EU law.

Focusing on a case study of product standards in the health sector, Röttger-Wirtz also highlights an incoherent approach on the part of the European Court of Justice towards the judicial review of these standards. She explains that, in this sector, standards become relevant through two distinct regulatory techniques. Pharmaceutical standards are developed in the form of soft law: the standards are found in guidance documents by the European Medicines Agency, often implementing standards set on the global level.

47 For example Ellen-Marie Forsberg, 'Standardisation in the Field of Nanotechnology: Some Issues of Legitimacy' (2012) Science and Engineering Ethics 18(4): 719-39.

48 Schmidt, supra n. 36, 2.

49 Ibid, 113. 
Contrary to this, for medical devices, European harmonised standards are used. Röttger-Wirtz explains that, although these standards largely fulfil similar regulatory functions, their judicial control by the Court of Justice is approached very differently. This is because there is little doubt left today concerning the fact that European harmonised standards can be judicially controlled by the Court, while guidance documents containing pharmaceutical standards are largely barred from judicial review.

Cuccuru and Bevilacqua concentrate instead on the procedural side of the standardisation process to assess its throughput legitimacy. In this context, in relation to global food safety standards, Bevilacqua questions whether the Codex standard-setting process provides for sufficient procedural guarantees of fairness and transparency. For example, Bevilacqua argues that the absence of a proper motivation of the standards makes it hard to trace the steps of every procedure leading to a certain standard and to understand its scientific and political rationale. Furthermore, he points out that, although transparency requirements have been extended in the context of the standard-setting procedure, 'to date, a significant prevalence of industry and trade-related interests can be identified, while health and consumer protection are still underrepresented'. ${ }^{50}$

This latter point resonates with De Bellis' conclusion with respect to global financial standards. She points out that, for a long time, global financial standard-setters have operated in complete secrecy. During the past 15 years they have started following notice and comment procedures and there is increasing attention to the application of due process requirements. Still, these differ significantly between the standard-setters.

Focusing on the process of European standardisation, Cuccuru brings to the fore a novelty in the process which may seemingly bring about advantages in terms of throughput legitimacy: the Commission's practice, following the Lisbon Treaty, to issue standardisation mandates to request harmonised European Standards in the shape of the Commission's 'implementing acts' in the meaning of Article 291 TFEU. He argues that the attempts to infuse stronger public law guarantees in the process, and hence to enhance its legitimacy, are more of a 'window dressing' exercise than a real 'game changer' for the process. This is, in his opinion, because the way in which mandates are drafted, monitored and enforced shows that 'public powers may not necessarily take the lead in the "implementation" of EU product harmonisation measures'. ${ }^{51}$ Furthermore, private monitoring mechanisms are in place to assess the compliance of standardisation activities with the underlying legis-

$50 \quad$ Bevilacqua, p. 263.

51 Cuccuru, p. 63. 
lative requirements and the standardisation mandate. Finally, the lack of any sanction under public law in case of non-compliance with standardisation requests shows that, in substance, these mandates are akin to contracts between the Commission and the European Standardisation Organisations.

Finally, the contribution by Senden takes an unusual yet essential perspective on the throughput legitimacy of the European standardisation process. She shifts the attention from the norm creation to the norm enforcement phase of the standardisation process, and focuses on the role of the individual as a compliance agent in the process. The questions she raises concern the 'compliance procedures by which to implement the standards in daily practice by companies, employers, service providers and other business operators affected by them, ${ }^{52}$ and in particular how transparent, accessible, accountable and efficient such procedures are. She concludes the current framework, set up by the Standardisation Regulation, does not ensure sufficient openness and accessibility of harmonised European standards because of financial, copyright and language obstacles.

\subsection{Legitimacy: What's in a Name?}

Legitimacy, and its components 'input', 'output' and 'throughput' legitimacy, are typically concepts used in public law literature. Nevertheless, their substance often plays a role in other fields of law too, albeit under different names. The contributions to this book examine this point with respect to private law and law and economics.

As van Leeuwen explains, private law recognises the concept of legitimacy, but instead of input and throughput legitimacy private lawyers speak of 'procedural legitimacy', and instead of 'output legitimacy' they speak of 'substantive legitimacy' of standards. From a procedural point of view, civil courts will assess whether the standard has been made by a group or institution which is representative of the profession, and whether it has been adopted following the usual procedures for adopting standards in the sector. From a substantive point of view, civil courts will evaluate the quality of the provisions of a standard and in particular whether the standard is of sufficient quality to be used and whether it represents the current professional standard in the sector. In effect, therefore 'private law effectively conducts a legitimacy test of European standardisation'. ${ }^{53}$

However, van Leeuwen shows in his chapter that at the moment a lack of dialogue between the relevant sectors and the European standardisation

Senden, p. 28.

53 van Leeuwen, p. 112. 
organisations prevents standards, especially in the field of services, from having a strong legitimacy in the sectors concerned. In particular, he shows that, in order to increase the use of standards in private law, the methodology of the standardisation process would have to be improved to include more evidence-based standardisation (so as to improve its output legitimacy), that the European Standardisation Organisations would have to provide clearer representation requirements for stakeholders and that they should do more to gain the support of those stakeholders (as a means to enhance its input and throughput legitimacy). However, at the moment, the parties involved in European standardisation do not develop standards with a view of them being applied in private law. As a consequence, the potential for private law to boost the legitimacy of the standardisation process remains largely unexploited.

Another private law perspective is offered by Rott and Glinski. They also show, from a specific tort law perspective, that there are commonalities "between "output legitimacy" and the substantive correctness of standards as well as between "input legitimacy" and the determination of liability for an objectively deficient standard'. ${ }^{4}$ The authors conclude that the risk for ESOs to incur tort liability for drafting unsafe HESs appears to be limited where the legitimacy requirements built into the system for the adoption of such standards are respected. The other side of the coin is that the risk of incurring tort liability functions as an incentive for the ESOs to comply with those legitimacy requirements. ${ }^{55}$

Finally, Faure and Philipsen point out that what lawyers discuss as legitimacy concerns are dealt with in the literature of law and economics as the danger of capture by special interest groups. Capture occurs when special interest groups influence the standard-setting process in such a way as to protect their own interests instead of the public interest. Faure and Philipsen point out that in some cases market and reputational mechanisms may prevent capture, but that this will not always be sufficient. This could be remedied by a variety of mechanisms increasing the accountability of private standard-setters and transparency of the private standard-setting process, and eventually even allowing public participation. Such measures would guarantee a certain level of legitimacy.

\footnotetext{
54 Rott and Glinski, p. 132.

55 Rott and Glinski, p. 150 and p. 155. In this regard, tort law plays a role that is comparable to that of competition law: the threat of incurring competition law sanctions should induce ESOs to comply with the safe harbour requirements set out in the Commission's Guidelines for Horizontal Cooperation Agreements - which, as shown by Cauffman and Gérardy (p. 71 et seq.), correspond to a large extent with legitimacy requirements. However, this threat does not seem to suffice to induce the ESOs to apply very rigorous legitimacy safeguards.
} 


\section{CONCLUSIONS}

European and global standards are ever more pervasive in contemporary regulation, and they cover fields as diverse as food safety, cosmetics, lifts and accounting. Standards enter the European legal system in a variety of ways, relevant for public and private law alike, giving rise to a multitude of different legal questions. While the trade advantages of using standards in regulation are undeniable, and their flexibility and capacity to adapt to a fast-moving society are also undisputed, it is equally clear that an increasing number of standard-setting processes have departed from the purely private realm to enter the stage of public regulation. This inevitably raises the question of how to reconcile the output legitimacy of standardisation as a regulatory technique with its input and throughput legitimacy imperatives.

Research on European integration has shown that public support for the EU is influenced both by input legitimacy considerations and by the output legitimacy performance of public policy. ${ }^{56}$ Scharpf argues that input and output legitimacy mutually reinforce each other and no single dimension is enough to ensure legitimate State action. ${ }^{57}$ At the same time, it is an unresolved question whether the relationship between input and output legitimacy is 'one of synergy or trade-off'..$^{58}$

This is a thorny question for the standardisation process as well, on which further - interdisciplinary - research is necessary: would more involvement of various stakeholder organisations in the standardisation process really contribute to its input legitimacy? As there are no guarantees that the organisations taking part in the process accurately reflect the views of the wider public, the result would not necessarily lead to increased input legitimacy of the standardisation process. ${ }^{59}$ Second, would enhanced stakeholder involvement not make the process less efficient? Would enhancing input legitimacy, in other words,

56 Claudia Schrag Sternberg, 'Political Legitimacy between Democracy and Effectiveness: Trade-offs, Interdependencies, and Discursive Constructions by the EU Institutions' (2015) European Political Science Review 7(4): 615-38.

57 Scharpf, above n. 35, 43-8.

58 Karl-Oskar Lindgren and Thomas Persson, 'Input and Output Legitimacy: Synergy or Trade-off? Empirical Evidence from an EU Survey’ (2010) Journal of European Public Policy 17(4): 449-67, 405. They consider that in the first case, an increase in input legitimacy will also increase output legitimacy, but if the relationship is one of trade-off, any gains on the input side may be offset by corresponding losses on the output side.

59 This is the argument of Justin Greenwood, 'Organized Civil Society and Democratic Legitimacy in the European Union’ (2007) British Journal of Political Science 37(2): 333-57. 
not interfere with output legitimacy? ${ }^{90}$ Or, conversely, ought input and output legitimacy not be seen rather as mutually reinforcing each other? It has indeed been hypothesised that increased deliberation could, in turn, increase support for political outcomes by fostering greater consensus among the players, and that 'the mere fact that an actor is granted the opportunity to have his or her say on the matter may make the actor more likely to support the political outcome even if the actor ends up opposing the collective choice'. ${ }^{61}$ Whether these hypotheses apply to the standardisation process would need to be tested in practice.

60 Ibid.

${ }^{61}$ Lindgren and Persson, above n. 58, 453. 